\title{
Основні вимоги
}

\section{до викладання курсу неврології лікарям загальної практики - сімейної медицини}

\begin{abstract}
Резюме
У статті представлені навчально-педагогічні заходи, які розроблені і впроваджені у практику колективом кафедри неврології і рефлексотерапії для покращення підготовки лікарів за циклом «Загальна практика-сімейна медицина».
\end{abstract}

Ключові слова: сімейна медицина, неврологія, викладання.

Мета: полягає у забезпеченні необхідної професійної ерудиції, світогляду лікаря для проведення диференціального діагнозу і диференційованої терапії, а також формування у лікарів навичок, необхідних для неврологічного дослідження і діагностування найбільш частих або невідкладних уражень нервової системи.

вороби нервової системи внаслідок їхньої широкої розповсюдженості та соціальної значущості посідають одне з провідних місць у клінічній медицині. Опанування сімейними лікарями основ клінічної неврології грунтується на чіткій схемі викладання матеріалу. Вивчення патологї нервової системи базується на засвоєнні особливостей фізіологї та анатомї нервової системи, в т.ч. 11 соматичного та вегетативного відділів. Насамперед лікарі повинні ознайомитись із класифікацією захворювань нервової системи. У практиці сімейного лікаря найчастіше зустрічаються судинні, дисметаболічні, запальні, вертеброгенні, токсичні та інші ураження.
Основними завданнями курсу «Нервові хвороби» є: формування навичок неврологічного обстеження, виявленню симптомів ураження нервової системи, виокремленню неврологічних синдромів та обгрунтуванню топічного діагнозу;

— отримання лікарем загальної практики-сімейної медицини (ЗП-СМ) сучасних знань про етіологію, патогенез, клініку, діагностику, диференційну діагностику, лікування та профілактику захворювань нервової системи;

формування у лікаря клінічного неврологічного мислення, здатності самостійно встановити діагноз, провести і призначити необхідний комплекс обстеження та лікування неврологічних захворювань, невідкладних неврологічних станів та проводити профілактику захворювань нервової системи.

\section{Коротка характеристика дисципліни, іiї місце в навчальному процесі}

Викладання неврології для лікаря ЗП-СМ має важливе значення у його підготовці, адже у своїй діяльності йому неодмінно доведеться в певному обсязі вирішувати діагностичні, лікувальні та організаційні питання ведення як неврологічних хворих, так і пацієнтів з неврологічними проявами та ускладненнями будь-якої соматичної патологіi.. Основними завданнями у проведенні циклу з неврології $€$ ознайомлення лікарів з найбільш актуальними питаннями дисципліни, оволодіння принципами побудови неврологічного діагнозу (топічного та клінічного). Особливу увагу потрібно звернути на діагностику та лікування таких захворювань, як розлади мозкового кровообігу, пухлини головного і спинного мозку, захворювання i травми периферичної нервової системи, показання для нейрохірургічного втручання. У клінічному розборі необхідно підкреслювати важливість ранньої діагностики, потребу своєчасної госпіталізації хворих. Під час вивчення захворювань нервової системи особливо важливими $є$ знання диференціального діагнозу і схем лікування таких ургентних станів, як мозкова кома, гострий період інсульту, епілептичний статус, синдром Гієна-Барре, міастенічний криз тощо. 


\section{Зв'язок з іншими дисциплінами}

Викладання недільних циклів неврології в післядипломній освіті базується на попередній підготовці лікарів на інших кафедрах. Базові знання з анатомії, біології, медичної генетики, гістології та гістопатології, нормальної та патологічної фізіології, пропедевтики внутрішніх захворювань, загальної хірургіi, фармакології $є$ основою для опанування лікарями курсу загальної неврологіі. Отримані клінічні знання з курсу дерматовенерологіі, офтальмології, отоларингологіі, ендокринології, кардіології, гастроентерології, акушерства і гінекології, рентгенології дозволяють лікарям опанувати курс клінічної неврології, а також зміст дисципліни в цілому.

Знання, отримані лікарями на кафедрі неврології, необхідні для кращого розуміння перебігу, клінічної картини і лікування наступних захворювань:

- серцево-судинної системи (гіпертонічна хвороба, атеросклероз, тромбоемболії, серцева недостатність, гострі кардіалгічні синдроми);

окремих захворювань інфекційної природи (менінгіти, енцефаліти, ВІЛ-інфекції, туберкульоз, сифіліс, герпес, бореліоз, гельмінтози та ін.);

ендокринних захворювань (цукровий діабет, патологія гіпофіза, захворювання щитоподібної і паращитоподібної залоз);

— комплекс знань з міждисциплінарної проблеми (проблеми головного болю, порушень свідомості - охоплюють практично всі медичні спеціальності; розуміння іх етіопатогенезу допомагає лікарям у диференціальній діагностиці, формує клінічне мислення та алгоритм обстеження пацієнта).

Відомості про ураження нервової системи при системних захворюваннях (червоний вовчак, дерматоміозит, склеродермія, ревматоїдний артрит, антифосфоліпідний синдром та ін.) дозволять опанувати лікарям 3П-СМ матеріал курсу з дерматовенерологіі, ревматології і терапії. Отримані знання про неврологічні прояви дегенеративно-дистрофічних уражень хребта застосовуються в диференціальному діагнозі больових синдромів як гострих, так і хронічних, що стане в нагоді у вивченні таких дисциплін, як «Терапія», «Хірургія», «Акушерство», «Гінекологія», «Урологія», «Стоматологія», «Отоларингологія» та ін.). Окрему нішу займає курс з немедикаментозних методів лікування даної патології (рефлексотерапія, фізіотерапія, ЛФК).

Відповідно до вимог програми циклів підготовки лікарів ЗП-СМ у результаті вивчення дисципліни «Нервові хвороби» лікар повинен знати:

- симптоми і синдроми ураження нервової системи; - етіологію, патогенез, клініку, діагностику, лікування, реабілітацію та профілактику основних захворювань нервової системи;

- фізикальні методи обстеження нервової системи;

основні додаткові методи обстеження неврологічних хворих;

— лікарську тактику у невідкладних неврологічних станах;

- організацію догляду за неврологічними хворими, принципи реабілітаціі та профілактики хвороб нервової системи.
Лікар повинен вміти:

провести опитування та зібрати анамнез у неврологічного хворого;

д досліджувати неврологічний статус;

— виявити симптоми ураження нервової системи, встановити неврологічні синдроми, поставити топічний і попередній клінічний діагноз;

с скласти план обстеження неврологічного хворого;

口 оцінити результати основних додаткових методів обстеження;

в встановити клінічний діагноз основних неврологічних захворювань;

— провести екстрене лікування невідкладних неврологічних розладів;

- організувати догляд за неврологічним хворим;

здійснити реабілітацію та профілактику основних неврологічних захворювань.

Основні захворювання нервової системи, за яких лікар ЗП-СМ повинен встановити клінічний діагноз, призначити обстеження і лікування:

- гострі порушення мозкового кровообігу (минуще порушення мозкового кровообігу, ішемічний інсульт, крововилив у мозок, субарахноїдальний крововилив);

— гіпертензійний синдром при пухлинах головного мозку;

— гостра черепно-мозкова і спінальна травми;

- менінгіт, енцефаліт;

- епілептичний статус;

в міастенічні і холінергічні кризи;

- мігренозний статус;

- дифтерійна, порфірійна і гостра запальна демієлінізуюча (Гієн-Барре) полінейропатія;

- радикулопатія і рефлекторні м'язові синдроми;

- невропатія лицьового нерва;

невралгія трійчастого нерва;

оперізуючий герпес.

Лікар повинен набути навичок:

- опитування, збору скарг та анамнезу у неврологічного Хворого;

- дослідження неврологічного статусу:

- визначення рівня свідомості;

- дослідження рухової сфери: визначення обсягу, сили і темпу довільних рухів; дослідження тонусу м'язів і рефлексів; виявлення м'язової атрофіі;

- дослідження чутливості: больової, температурноі, пропріоцептивної; виявлення парестезій, каузалгіі;

дослідження функції черепних нервів;

- дослідження координаціі: проба Ромберга, координаторні проби в кінцівках (пальце-носова, п’ятково-колінна, адіадохокінез);

- дослідження менінгеальних симптомів;

- дослідження вищих мозкових функцій: мови, читання, письма, рахунку, гнозису, праксису, пам'яті та інтелекту;

— виявлення симптомів паркінсонізму;

дослідження вегетативних функцій: виявлення порушень терморегуляції, потовиділення, вазомоторних і трофічних розладів, ортостатичної гіпотензії, синдрому Рейно, порушення функції тазових органів;

дослідження хворого в коматозному стані, оцінка зіничних реакцій, виявлення вогнищевих неврологічних симптомів, проведення окулоцефалічних проб. 
На підставі дослідження неврологічного статусу виявити неврологічні симптоми і синдроми, встановити топічний та попередній клінічний діагноз.

Лікар повинен також знати показання та протипоказання до застосування додаткових клінічних та додаткових методів дослідження, вміти трактувати іхні результати:

п люмбальна пункція і дослідження спинномозкової рідини;

— краніографія і спондилографія;

- електронейроміографія;

- електроенцефалографія та методика дослідження викликаних потенціалів;

— рентгенівська комп'ютерна томографія головного і спинного мозку, різних відділів хребетного стовпа, магнітно-резонансна томографія головного і спинного мозку і різних відділів хребетного стовпа, ангіографія, однофотонна емісійна комп’ютерна томографія; ультразвукова доплерографія, ультразвукове дуплексне і триплексне сканування сонних і хребетних артерій, транскраніальна доплерографія; ехоенцефалоскопія і реоенцефалографія.

В результаті на підставі клінічного обстеження (з урахуванням додаткових методів обстеження) лікар повинен вміти встановити заключний клінічний діагноз при основних захворюваннях нервової системи. В разі необхідності лікар ЗП-СМ має бути готовим провести екстрену діагностику і призначити лікування пацієнтам з невідкладними неврологічними захворюваннями (ішемічному інсульті, крововиливах у мозок, субарахноїдальному крововиливі, гострій черепно-мозковій та спінальній травмі, епілептичному статусі, міастенічному і холінергічному кризі, менінгіті, енцефаліті); організувати догляд та реабілітацію неврологічного хворого, здійснити профілактику основних неврологічних захворювань.

\section{Главные требования к преподаванию неврологии врачам общей практики - семейной медицины}

\author{
Свиридова Н.К., Сулик Р.В., Середа В.Г., \\ Кусткова А.С., Пономаренко Ю.В. \\ Национальная медицинская академия \\ последипломного образования имени П.Л. Шупика, \\ кафедра неврологии и рефлексотерапии
}

\section{Резюме}

В статье представлены учебно-педагогические мероприятия, которые разработаны и внедрены в практику коллективом кафедры неврологии и рефлексотерапии для улучшения подготовки врачей цикла «Общая практика-семейная медицина»

Ключевые слова: семейная медицина, неврология, преподавание.

\section{The key requirements of teaching neurology to general practitioners and family doctors}

\section{N.K. Svyrydova, R.V. Sulik, V.G. Sereda,} A.S. Kustkova, Y.V. Ponomarehko

Shupyk National Medical Academy of Postgraduate Education,

Neurology and Reflexotherapy Department

\section{Summary}

The article outlines the educational and pedagogical methods that have been designed and implemented by the team of the Department of Neurology and reflexology to improve the training of physicians within the General practice and family medicine cycle.

Goal: to provide the necessary professional knowledge and broaden the scope of doctors to help differential diagnosis and differential therapy, as well as building up the skills needed for neurological examination and diagnosticating the most frequent cases or urgent lesions of the nervous system.

Keywords: medicine, neurology, teaching 